\title{
SYNTHESIS, STRUCTURE AND APPLICATION OF MIXED-LIGAND COORDINATION COMPOUNDS OF COPPER(II) WITH SUBSTITUTED THIOAMIDES
}

\author{
Anatoliy Ranskiy' ${ }^{\otimes}$, Olga Gordienko1, Natalia Didenko², Taras Titov', \\ Maryna Khutko ${ }^{1}$
}

https://doi.org/10.23939/chcht14.01.055

\begin{abstract}
New coordination compounds of copper(II) with substituted thioamides of the general formula $\left[\mathrm{Cu}\left(\mathrm{HL}^{6-9}\right)_{2} \mathrm{X}_{2}\right]_{2}$ and $\mathrm{CuL}_{2}{ }^{6-9}$ have been synthesized. The consecutive reaction of nucleophilic substitution/elimination of $\mathrm{S}_{\mathrm{N}}^{1} / \mathrm{E}_{1}$ in the octahedral complex $\left[\mathrm{Cu}\left(\mathrm{NH}_{3}\right)_{4} \mathrm{Cl}_{2}\right] \cdot \mathrm{H}_{2} \mathrm{O}$ and catalytic hydrolysis of $\left[\mathrm{Cu}\left(\mathrm{HL}^{6-9}\right)_{2} \mathrm{X}_{2}\right]_{2}$ complexes have been investigated. Using IR spectroscopy, elemental and XRD analysis, the composition and structure of the synthesized complexes have been determined. The molecular and crystalline structure of the complex $\left[\mathrm{Cu}\left(\mathrm{C}_{30} \mathrm{H}_{26} \mathrm{Cl}_{2} \mathrm{~N}_{6} \mathrm{O}_{8} \mathrm{~S}_{2}\right)\right] \cdot i$ $\mathrm{C}_{3} \mathrm{H}_{7} \mathrm{ON}$ was determined by $\mathrm{X}$-ray diffraction analysis. The tribotechnical characteristics of some coordination compounds as additives to industrial oils have been investigated.
\end{abstract}

Keywords: substituted thioamides, copper(II), coordination compounds, XRD, industrial oil.

\section{Introduction}

Previously, we have obtained and investigated the coordination compounds of copper(II) with benzimidazole-2-thiocarboxylic acid arylamides using the general scheme of the direct [1] and traditional [1,2] synthesis methods:

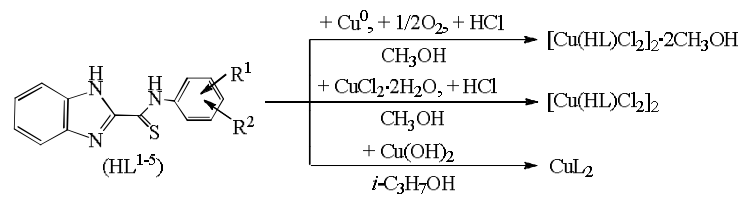

\footnotetext{
${ }^{1}$ Vinnytsia National Technical University, 95, Khmelnytske shose, 21021 Vinnytsia, Ukraine

${ }^{2}$ Vinnytsia National Pirogov Memorial Medical University

56, Pyrogova St., 21018 Vinnytsia, Ukraine

ranskiy@gmail.com

(C) Ranskiy A., Gordienko O., Didenko N., Titov T., Khutko M., 2020
}

$\mathrm{HL}^{1}: \mathrm{R}^{1}=\mathrm{H}, \mathrm{R}^{2}=4-\mathrm{OC}_{2} \mathrm{H}_{5} ; \mathrm{HL}^{2}: \mathrm{R}^{1}=\mathrm{H}, \mathrm{R}^{2}=2-\mathrm{Cl} ; \mathrm{HL}^{3}$ : $\mathrm{R}^{1}=2-\mathrm{CH}_{3}, \mathrm{R}^{2}=4-\mathrm{CH}_{3} ; \mathrm{HL}^{4}: \mathrm{R}^{1}=\mathrm{H}, \mathrm{R}^{2}=3-\mathrm{CH}_{3} ; \mathrm{HL}^{5}$ : $\mathrm{R}^{1}=\mathrm{H}, \mathrm{R}^{2}=3-\mathrm{CF}_{3}$.

Depending on the copper(II) salt or powder copper, organic solvent and the reaction conditions $(t, \tau, \mathrm{pH})$ the coordination compounds of the general formula $\mathrm{CuL}_{2}$ [2] and $\left[\mathrm{Cu}(\mathrm{HL}) \mathrm{Cl}_{2}\right]_{2} \cdot 2 \mathrm{CH}_{3} \mathrm{OH}$ [1] were synthesized. The compounds were investigated by the XRD method and the dimer spatial structure was specified for $\left[\mathrm{Cu}(\mathrm{HL}) \mathrm{Cl}_{2}\right]_{2} \cdot 2 \mathrm{CH}_{3} \mathrm{OH}$. These coordination compounds, which include deprotonated and neutral thioamide ligands, exhibit antiwear, anticorrosion, antifriction and antioxidant properties as additives to lubricants and oils [3], as well as properties of biologically active compounds [6], which served as an additional incentive to their purposeful research.

In the continuation of the above-mentioned works, we investigated new methods for the synthesis of coordination compounds and investigated the mutual transitions $\left[\mathrm{Cu}\left(\mathrm{HL}^{6-9}\right)_{2} \mathrm{X}_{2}\right]_{2} \rightleftharpoons 2 \mathrm{CuL}_{2}^{6-9}$ according to the following scheme:

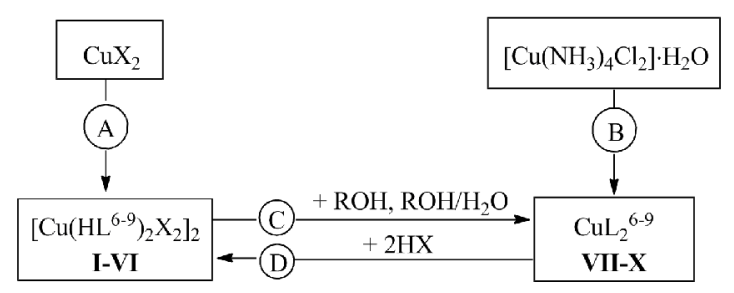

Methods A-D, benzimidazole-2- $N$-arylcarbothioamide $\mathrm{HL}^{6-9}: \mathrm{HL}^{6}: \mathrm{R}=2-\mathrm{CH}_{3}, \mathrm{HL}^{7}: \mathrm{R}=4-\mathrm{Br}, \mathrm{HL}^{8}$ : $\mathrm{R}=3-\mathrm{CF}_{3}, \quad \mathrm{HL}^{9}: \mathrm{R}=3-\mathrm{Br} ; \quad \mathbf{I}: \mathrm{R}=2-\mathrm{CH}_{3}, \mathrm{X}=\mathrm{ClO}_{4} ; \quad \mathbf{I I}$ : $\mathrm{R}=4-\mathrm{Br}, \mathrm{X}=\mathrm{ClO}_{4}$; III: $\mathrm{R}=3-\mathrm{CF}_{3}, \mathrm{X}=\mathrm{ClO}_{4} ; \mathrm{IV}: \mathrm{R}=3-\mathrm{Br}$, $\mathrm{X}=\mathrm{BF}_{4} ; \mathrm{V}: \mathrm{R}=4-\mathrm{Br}, \mathrm{X}=\mathrm{BF}_{4} ; \mathrm{VI}: \mathrm{R}=3-\mathrm{CF}_{3}, \mathrm{X}=\mathrm{BF}_{4} ; \mathrm{VII}$ : $\mathrm{CuL}_{2}^{6}$; VIII: $\mathrm{CuL}_{2}^{7} ; \mathbf{I X}: \mathrm{CuL}_{2}^{8} ; \mathbf{X}: \mathrm{CuL}_{2}^{9}$.

The purpose of this work is the synthesis of new coordination compounds of copper(II) with substituted thioamides $\mathrm{HL}^{6-9}$, the investigation of their structure and 
study of mutual transition of one form of coordination compounds into another during chemical transformations.

\section{Experimental}

\subsection{Materials and Methods}

To obtain coordination compounds of the general formula $\mathrm{CuL}_{2}^{6-9}$ and $\left[\mathrm{Cu}\left(\mathrm{HL}^{6-9}\right)_{2} \mathrm{X}_{2}\right]_{2}$, the initial benzimidazole-2- $N$-arylcarbothioamides $\mathrm{HL}^{6-9}$ were synthesized according to the procedure given in [1] and the initial dichlorotetraaminecopper(II) -via reaction between copper(II) chloride and concentrated solution of ammonium. Other used inorganic salts of copper(II) and organic solvents were of pure grade. The content of copper(II) in the synthesized complexes I-X was determined by a complexometric titration with ethylenediaminetetraacetic acid (EDTA). The content of nitrogen was determined by an elemental analysis using Kjeldahl method, and sulfur content - using Sheniger method [4].

IR spectra of compounds I-X in the range of 4000$400 \mathrm{~cm}^{-1}$ were recorded on the Specord 75 IR device; the samples were prepared as tablets with $\mathrm{KBr}$.

For X-ray studies the monocrystalline diperchlorato-bis[benzimidazole-2- $N$-(2-methylphenyl)carbothioamide]copper(II) dimer solvated by isopropyl alcohol (compound XI) was obtained by slow evaporation of the saturated solution of coordination compound $\mathbf{I}$ in isopropyl alcohol. The study was performed at $100 \mathrm{~K}$ using a Xcalibur-3 diffractometer $\left(\mathrm{MoK}_{\alpha}\right.$ radiation, $\mathrm{CCD}-$ detector, graphite monochromator, $\omega$-scan, $2 \theta_{\max }=55^{\circ}$ ). In total there are 27026 images, 6600 of them are independent, $R_{\text {int }}=0.088$. The crystals are monoclinic, spatial group $\mathrm{P} 2_{1 / \mathrm{n}} ; a=11.792(4) \AA, b=21.235(1) \AA$, $c=15.254(4) \AA ; \beta=109.47(4)^{\circ}, V=3756(4) \AA^{3}$, $z=4$. For $\mathrm{C}_{30} \mathrm{H}_{26} \mathrm{Cl}_{2} \mathrm{~N}_{6} \mathrm{O}_{8} \mathrm{~S}_{2} \mathrm{Cu} \cdot \mathrm{C}_{3} \mathrm{H}_{7} \mathrm{OH} \quad M_{r}=$ $=856.5 \mathrm{~g} / \mathrm{mol}, \rho_{\text {calc }}=1.516 \mathrm{~g} / \mathrm{cm}^{3}, \mu\left(\mathrm{MoK}_{\alpha}\right)=0.900 \mathrm{~mm}^{-1}$, $F(000)=1764$.

The structure was decoded by a direct method using the SHELXTL program [5]. The positions of the hydrogen atoms were found from the difference in an electron density and are specified according to the "rider" model with $U_{\text {iso }}=n \cdot U_{e q}$ of a non-hydrogen atom bound with hydrogen one ( $n=1.5$ for methyl groups and $n=1.2$ for other atoms of hydrogen). The components structure was specified by the least-squares method relative to $F^{2}$ in a full-matrix anisotropic approximation for non-hydrogen atoms up to $w R_{2}=0.11$ relative to 6478 reflections $\left(R_{1}=0.09\right.$ relative to 5621 reflections with $F>4 \sigma(F)$, $S=1.087)$.

Antiwear $\left(I_{g}\right)$ and antifriction $\left(f_{f r}\right)$ properties of lubricant compositions based on I-40 industrial oil and some I-X synthesized compounds were determined using SMTs-2 friction machine with a "bronze-steel" friction pair with a slip velocity of $3.0 \mathrm{~m} / \mathrm{s}$ and sliding distance of $3 \cdot 10^{3} \mathrm{~m}$. Roller material was Steel-45, pads material bronze BrAZh 9-4. Coefficient of mutual overlap was 0.13 . Initial roughness was $0.30-0.62 \mu \mathrm{m}$ for a steel sample and $0.62-0.80 \mu \mathrm{m}$ - for a bronze one. Wear was recorded by a gravimetric method using the analytical scales with the second-grade accuracy. The temperature in the friction zone was measured by a chromel-copel thermocouple, and the friction force - with the help of a strain gauge.

\subsection{Synthesis of Coordination Compounds of the General Formula $\left[\mathrm{Cu}\left(\mathrm{HL}^{6-9}\right)_{2} \mathrm{X}_{2}\right]_{2}$}

\subsubsection{Diperchlorato-bis[benzimidazole-2- $N$ -}

\section{(4-bromophenyl)carbothioamide]copper(II) Dimer, II}

Method A. $1.9 \mathrm{~g}(5.1 \mathrm{mmol})$ of $\mathrm{Cu}\left(\mathrm{ClO}_{4}\right)_{2} \cdot 6 \mathrm{H}_{2} \mathrm{O}$ dissolved in $10 \mathrm{ml}$ of hot anhydrous isopropyl alcohol, acidified by $2.6 \mathrm{ml}(3.0 \mathrm{mmol})$ of $69 \% \mathrm{HClO}_{4}$ were added under stirring to a solution of $3.32 \mathrm{~g}(10.0 \mathrm{mmol})$ of benzimidazole-2- $N$-(4-bromophenyl)carbothioamide in $200 \mathrm{ml}$ of the same solvent. The reaction mixture was kept at $323-333 \mathrm{~K}$ for $1-1.2 \mathrm{~h}$ and then cooled to room temperature. The resulting green-brown precipitate was filtered off, washed with an isopropyl alcohol $(3 \times 30 \mathrm{ml})$ and dried in air at room temperature. Yield: $4.4 \mathrm{~g}(95 \%)$, m.p. (decomp.) 508-512 K. Found, \%: N 8.82; S 7.28; Cu 6.52. For $\left[\mathrm{Cu}\left(\mathrm{C}_{28} \mathrm{H}_{20} \mathrm{Br}_{2} \mathrm{Cl}_{2} \mathrm{~N}_{6} \mathrm{O}_{8} \mathrm{~S}_{2}\right)\right]$ calcd., \%: $\mathrm{N}$ 9.07; $\mathrm{S}$ 6.92; $\mathrm{Cu}$ 6.86. IR ( $\left.\mathrm{KBr}, v, \mathrm{~cm}^{-1}\right): \mathrm{NH}_{\text {het }} 3075 \mathrm{w}$; "B"-band 1585 m, 1550 m, 1485 s, 1425 s; "D”-band 1286 m, 1180 m, 1157 m; "E"-band 970 m, $740 \mathrm{~s} ;\left(v, \mathrm{ClO}_{4}\right) 1080 \mathrm{~s}$.

Method D. $4.2 \mathrm{ml}(4.8 \mathrm{mmol})$ of $69 \% \mathrm{HClO}_{4}$ were added to $5.8 \mathrm{~g}(8.0 \mathrm{mmol})$ of bis[benzimidazole-2- $\mathrm{N}-(4-$ bromophenyl)carbothioamide]copper(II) suspension in $100 \mathrm{ml}$ of anhydrous isopropyl alcohol. The reaction mixture was kept under stirring at $323-333 \mathrm{~K}$ for $1.5 \mathrm{~h}$ and then cooled to room temperature. The green-brown precipitate was filtered off, washed with isopropyl alcohol $(3 \times 20 \mathrm{ml})$ and dried at room temperature. Yield $6.75 \mathrm{~g}$ (91 \%), m.p. (decomp.) 504-510 K. Found, \%: N 8.82, S 7.28, $\mathrm{Cu}$ 6.52. For $\left[\mathrm{Cu}\left(\mathrm{C}_{30} \mathrm{H}_{26} \mathrm{Cl}_{2} \mathrm{~N}_{6} \mathrm{O}_{8} \mathrm{~S}_{2}\right)\right]$ calcd., \%: $\mathrm{N}$ $9.07, \mathrm{~S} 6.92, \mathrm{Cu} 6.86$. The characteristic stretching vibrations in the IR spectrum of compound II, obtained by method $\mathrm{D}$, are identical with those obtained by the method $\mathrm{A}$.

Compounds I, III-VI were synthesized similar to the above-mentioned methods A and D. 


\subsubsection{Diperchlorato-bis[benzimidazole-2- $N$ - (2-methylphenyl)carbothioamide]copper(II) Dimer, I}

Method A. The dark-green microcrystalline precipitate. Yield $2.52 \mathrm{~g} \quad(63 \%)$, m.p. (decomp.) $508-511 \mathrm{~K}$. Found, \%: N 10.25; S 7.87; Cu 8.16. For $\left[\mathrm{Cu}\left(\mathrm{C}_{30} \mathrm{H}_{26} \mathrm{Cl}_{2} \mathrm{~N}_{6} \mathrm{O}_{8} \mathrm{~S}_{2}\right)\right]$ calcd., \%: N 10.54; $\mathrm{S} 8.04 ; \mathrm{Cu}$ 7.97. IR $\left(\mathrm{KBr}, v, \mathrm{~cm}^{-1}\right)$ : $\mathrm{NH}_{\text {het }} 3066 \mathrm{w}$; "B"-band 1508 v.s, $1463 \mathrm{~m}, 1440 \mathrm{~m}, 1425 \mathrm{~s}$; "D"-band 1262 v.s, $1176 \mathrm{~m}$, 1106 m; "E"-band 966 m, 940 m, 831 s, 740 v.s, 625 m; $\left(v, \mathrm{ClO}_{4}\right) 1028 \mathrm{~s}, 520 \mathrm{w}$.

\subsubsection{Diperchlorato-bis[benzimidazole-2- $N$ - (3-trifluoromethylphenyl)carbothioamide] copper(II) Dimer, III}

Method D. The dark-green microcrystalline precipitate. Yield $4.85 \mathrm{~g}$ (67\%), m.p. (decomp.) 532-534 K. Found, \%: N 8.83; S 6.64; $\mathrm{Cu}$ 7.38. For $\left[\mathrm{Cu}\left(\mathrm{C}_{30} \mathrm{H}_{20} \mathrm{Cl}_{2} \mathrm{~F}_{6} \mathrm{~N}_{6} \mathrm{O}_{8} \mathrm{~S}_{2}\right)\right]$ calcd., \%: N 9.29; $\mathrm{S}$ 7.09; $\mathrm{Cu}$ 7.02. IR (KBr, $\left.v, \mathrm{~cm}^{-1}\right)$ : $\mathrm{NH}_{\text {het }} 3050 \mathrm{w}$; "B"-band $1560 \mathrm{~m}$, $1515 \mathrm{~m}, 1420 \mathrm{~s}$; "D"-band $1325 \mathrm{~m}, 1200 \mathrm{w}, 1115 \mathrm{~m}$; "E"band $963 \mathrm{~m}, 740 \mathrm{~s} ;\left(v, \mathrm{ClO}_{4}\right) 1030 \mathrm{~m}$.

\subsubsection{Ditetrafluoroborato-bis[benzimidazole- 2- $N$-(3-bromophenyl)carbothioamide]copper(II) Dimer, IV}

Method A. The green-brown microcrystalline precipitate. Yield $3.24 \mathrm{~g} \quad$ (72\%), m.p. (decomp.) 493-503 K. Found, \%: N 9.04; S 6.78; Cu 6.91. For $\left[\mathrm{Cu}\left(\mathrm{C}_{28} \mathrm{H}_{20} \mathrm{Br}_{2} \mathrm{~F}_{8} \mathrm{~B}_{2} \mathrm{~N}_{6} \mathrm{~S}_{2}\right)\right]$ calcd., \%: N 9.32; $\mathrm{S} 7.11 ; \mathrm{Cu}$ 7.05. IR $\left(\mathrm{KBr}, v, \mathrm{~cm}^{-1}\right)$ : $\mathrm{NH}_{\text {het }} 3030 \mathrm{w}$; “B”-band $1587 \mathrm{~m}$, $1535 \mathrm{~s}, 1465 \mathrm{~s}, 1420 \mathrm{~s}$; "D"-band $1330 \mathrm{~m}, 1295 \mathrm{~m}, 1185$ w, $1160 \mathrm{~m}$; "E"-band $950 \mathrm{~m}, 840 \mathrm{~m}$; $\left(v, \mathrm{BF}_{4}\right) 1030 \mathrm{~m}$.

\subsubsection{Ditetrafluoroborato-bis[benzimidazole-2- $N$ - (4-bromophenyl)carbothioamide]copper(II) Dimer, V}

Method A. The green-brown microcrystalline precipitate. Yield $4.38 \mathrm{~g}$ (97\%), m.p. (decomp.) 500$501 \mathrm{~K}$. Found, \%: N 9.64; S 6.77; $\mathrm{Cu}$ 7.35. For $\left[\mathrm{Cu}\left(\mathrm{C}_{28} \mathrm{H}_{20} \mathrm{Br}_{2} \mathrm{~F}_{8} \mathrm{~B}_{2} \mathrm{~N}_{6} \mathrm{~S}_{2}\right)\right]$ calcd., \%: N 9.32; $\mathrm{S} 7.11 ; \mathrm{Cu}$ 7.05. IR (KBr, $\left.v, \mathrm{~cm}^{-1}\right)$ : $\mathrm{NH}_{\text {het }} 3075 \mathrm{w}$; "B"-band $1585 \mathrm{~m}$, 1550 m, 1485 s, 1427 s; "D"-band 1325 m, 1283 m, 1190 w, $1155 \mathrm{~m}$; "E"-band $947 \mathrm{~m}, 834 \mathrm{~m}$; $\left(v, \mathrm{BF}_{4}\right) 1080 \mathrm{~m}$, $1035 \mathrm{~m}, 760 \mathrm{~m}, 525 \mathrm{~m}$.

2.2.6. Ditetrafluoroborato-bis[benzimidazole-2- $N$ (3-fluoromethylphenyl)carbothioamide]copper(II) Dimer, VI

Method A. The dark-green microcrystalline precipitate. Yield $4.18 \mathrm{~g}$ (95\%), m.p. (decomp.)
$523-525 \mathrm{~K}$. Found, \%: N 9.14; S 7.03; Cu 7.45. For $\left[\mathrm{Cu}\left(\mathrm{C}_{30} \mathrm{H}_{20} \mathrm{~F}_{14} \mathrm{~B}_{2} \mathrm{~N}_{6} \mathrm{~S}_{2}\right)\right]$ calcd., \%: N 9.55; S 7.29; $\mathrm{Cu}$ 7.22. IR (KBr, $\left.v, \mathrm{~cm}^{-1}\right)$ : $\mathrm{NH}_{\text {het }} 3045 \mathrm{~m}$; "B"-band $1560 \mathrm{~m}$, 1517 m, 1165 s, 1420 s; "D"-band 1330 m, 1290 m, 1180 w, 1165 w; "E"-band $950 \mathrm{~m}, 840 \mathrm{~m}$; $\left(v, \mathrm{BF}_{4}\right) 1080 \mathrm{~s}, 1035$ $\mathrm{m}, 760 \mathrm{~m}, 525 \mathrm{~m}$.

\subsection{Synthesis of Coordination Compounds of the General Formula $\mathrm{CuL}_{2}{ }^{6-9}$}

\subsubsection{Bis[benzimidazole-2- $N$ -}

(4-bromophenyl)carbothioamide]copper(II), VIII

Method B. $0.4 \mathrm{~g}(10.0 \mathrm{mmol})$ of $\mathrm{NaOH}$ in $10 \mathrm{ml}$ of water-methanol $(1: 1)$ solution were added under stirring to $3.32 \mathrm{~g} \quad(10.0 \mathrm{mmol})$ of benzimidazole-2- $N$-(4-bromophenyl)carbothioamide in $150 \mathrm{ml}$ of hot methanol. Then $1.1 \mathrm{~g}(5 / 0 \mathrm{mmol})$ of $\left[\mathrm{Cu}\left(\mathrm{NH}_{3}\right)_{4} \mathrm{Cl}_{2}\right] \cdot \mathrm{H}_{2} \mathrm{O}$ in $10 \mathrm{ml}$ of water-methanol (1:1) solution were dropped under intensive stirring. The reaction mixture was kept at $323-333 \mathrm{~K}$ for $20 \mathrm{~min}$. The resulting dark-brown precipitate was filtered off, washed successively with methanol and hot water and dried at $373 \mathrm{~K}$ till the constant mass. Yield: $3.52 \mathrm{~g} \mathrm{(97 \% ),}$ m.p. (decomp.) 527-530 K. Found, \%: N 11.41; S 8.54; $\mathrm{Cu}$ 9.02. For $\left[\mathrm{Cu}\left(\mathrm{C}_{28} \mathrm{H}_{18} \mathrm{Br}_{2} \mathrm{~N}_{6} \mathrm{~S}_{2}\right)\right]$ calcd., \%: $\mathrm{N}$ 11.58; $\mathrm{S}$ 8.83; $\mathrm{Cu}$ 8.75. IR $\left(\mathrm{KBr}, v, \mathrm{~cm}^{-1}\right): \mathrm{NH}_{\text {het }} 3060 \mathrm{w}$; "B"-band $1565 \mathrm{~m}, 1520 \mathrm{~m}, 1450 \mathrm{~s}$; "D"-band $1395 \mathrm{~m}, 1325 \mathrm{~m}, 1150$ m, 1125 m; "E"-band 945 m, 745 s.

Method C. $50 \mathrm{ml}$ of the solvent (alcohol, water) were added to $10.22 \mathrm{~g}(10.0 \mathrm{mmol})$ of diperchloratobis[benzimidazole- $2-N-(4-$

bromophenyl)carbothioamide]copper(II). The reaction mixture was stirred at room temperature for $15 \mathrm{~min}$. The dark-brown precipitate was washed with methanol and dried in the air. Yield $6.68 \mathrm{~g}$ (92\%), m.p. (decomp.) 525-528 K. Found, \%: N 11.23, S 8.33, Cu 8.52. For $\left[\mathrm{Cu}\left(\mathrm{C}_{28} \mathrm{H}_{18} \mathrm{Br}_{2} \mathrm{~N}_{6} \mathrm{~S}_{2}\right)\right]$ calcd., \%: N 11.58, S 8.83, $\mathrm{Cu} 8.75$. The characteristic stretching vibrations in the IR spectrum of compound VIII, obtained by the method C, are identical with those obtained by the method B.

Compounds VII, IX and $\mathbf{X}$ were synthesized similar to the above-mentioned methods B and C.

\subsubsection{Bis[benzimidazole- $-2-N$ -}

\section{(2-methylphenyl)carbothioamide]copper(II), VII}

Method B. The dark-brown microcrystalline precipitate. Yield $2.74 \mathrm{~g}$ (92\%), m.p. (decomp.) 519$525 \mathrm{~K}$. Found, \%: N 13.83; S 10.55; $\mathrm{Cu} 10.98$. For $\left[\mathrm{Cu}\left(\mathrm{C}_{30} \mathrm{H}_{24} \mathrm{~N}_{6} \mathrm{~S}_{2}\right)\right]$ calcd., \%: N 14.10; S 10.76; Cu 10.66. IR (KBr, $\left.v, \mathrm{~cm}^{-1}\right)$ : $\mathrm{NH}_{\text {het }} 3070 \mathrm{w}, 3020 \mathrm{w}$; “B”-band 1565 m, 1520 m, 1457 s; "D"-band 1280 m, 1130 m; "E"-band $955 \mathrm{~m}, 750 \mathrm{~s}$. 


\subsubsection{Bis[benzimidazole-2- $N$-(3-}

\section{trifluoromethylphenyl)carbothioamide] copper(II), IX}

Method B. The dark-brown microcrystalline precipitate. Yield $3.27 \mathrm{~g}(93 \%)$, m.p. (decomp.) $\geq 483 \mathrm{~K}$. Found, \%: $\mathrm{N} 11.64 ; \mathrm{S}$ 8.85; $\mathrm{Cu}$ 8.76. For $\left[\mathrm{Cu}\left(\mathrm{C}_{30} \mathrm{H}_{18} \mathrm{~F}_{6} \mathrm{~N}_{6} \mathrm{~S}_{2}\right)\right]$ calcd., \%: N 11.93; $\mathrm{S} 9.11 ; \mathrm{Cu} 9.02$. IR $\left(\mathrm{KBr}, v, \mathrm{~cm}^{-1}\right)$ : $\mathrm{NH}_{\text {het }} 3070 \mathrm{w}$; "B"-band $1565 \mathrm{~m}, 1535 \mathrm{~m}$, 1475 m; "D"-band 1285 m, 1207 m; "E”-band 955 m, 747 s.

\subsubsection{Bis[benzimidazole-2- $N$ -}

\section{(3-bromophenyl)carbothioamide]copper(II), X}

Method C. The brown microcrystalline precipitate. Yield 6.83 g (94 \%), m.p. (decomp.) 499-502 K. Found, \%: N 11.43; $\mathrm{S} 8.40 ; \mathrm{Cu}$ 9.05. For $\left[\mathrm{Cu}\left(\mathrm{C}_{28} \mathrm{H}_{18} \mathrm{Br}_{2} \mathrm{~N}_{6} \mathrm{~S}_{2}\right)\right]$ calcd., \%: N 11.58; S 8.83; $\mathrm{Cu} 8.75$. IR ( $\left.\mathrm{KBr}, v, \mathrm{~cm}^{-1}\right)$ : $\mathrm{NH}_{\text {het }} 3095$ w; "B"-band 1575 s, 1529 s, 1488 m, 1458 v.s; "D"-band 1395 s, 1322 m, 1100 s, 1056 s; "E"-band 746 v.s, 730 s.

\section{Results and Discussion}

\subsection{Consecutive Reaction of Nucleophilic Substitution/Elimination $\mathrm{S}_{\mathrm{N}}{ }^{1} / \mathrm{E}_{1}$ in the Octahedral Complex $\left[\mathrm{Cu}\left(\mathrm{NH}_{3}\right)_{4} \mathrm{Cl}_{2}\right] \cdot \mathrm{H}_{2} \mathrm{O}($ Method B)}

The synthesis principles for coordination compounds of copper(II) with heterocyclic thioamides of the general formula $\mathrm{CuL}_{2}$ depending on the nature of the thioamide ligand $(\mathrm{HetC}(=\mathrm{S}) \mathrm{NHAr})$, organic solvent $(\mathrm{ROH}$ or $\mathrm{ROH}+\mathrm{H}_{2} \mathrm{O}$ ), the initial salt of $\mathrm{CuX}_{2}$ ( $\mathrm{X}$ is the acidic residue of strong or weak acid) and the reaction conditions (medium $\mathrm{pH}, t, \tau$ ) are given in a series of works $[2,10]$. In this work we have developed a new method for the synthesis of coordination compounds $\mathrm{CuL}_{2}^{6-9}$ VII-X according to the scheme:

$$
\begin{aligned}
& {\left[\mathrm{Cu}\left(\mathrm{NH}_{3}\right)_{4} \mathrm{Cl}_{2}\right] \cdot \mathrm{H}_{2} \mathrm{O}+\mathrm{HL}^{6-9} \rightleftharpoons}
\end{aligned}
$$

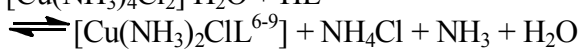

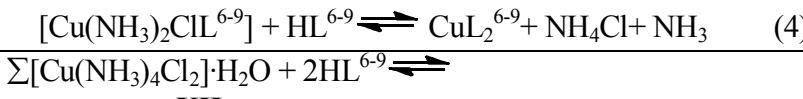

$$
\begin{aligned}
& \text { XII } \\
& \rightleftharpoons \mathrm{CuL}_{2}{ }^{6-9}+2 \mathrm{NH}_{4} \mathrm{Cl}+2 \mathrm{NH}_{3}+\mathrm{H}_{2} \mathrm{O} \\
& \text { VII-X }
\end{aligned}
$$

Taking into account the total Eq. (5) we assert that the reaction takes place in two stages according to the mechanism of $\mathrm{S}_{\mathrm{N}}{ }^{1}$ nucleophilic substitution of amyacate ligands (according to Pearson acid base concept (HSAB concept) $\mathrm{NH}_{3}$ is a hard basis) for the thioamidic ligand (according to $\mathrm{HSAB}$ concept $\mathrm{HL}^{6-9}$ is an intermediate basis). Moreover, $\mathrm{Cu}^{2+}$ cation is an intermediate acid, and $\mathrm{CuL}_{2}^{6-9}$ chelates with the trans-coordination unit $\mathrm{CuN}_{2} \mathrm{~S}_{2}$ are formed as a result of the reaction; so this version of the substitution reaction via $\mathrm{S}_{\mathrm{N}}{ }^{1}$ mechanism could be considered as a non-alternative one. However, a detailed analysis of the results (Eqs. (3)-(5)) indicates the more complex nature of the investigated chemical transformations, which are shown by general scheme $(6)^{\wedge}$

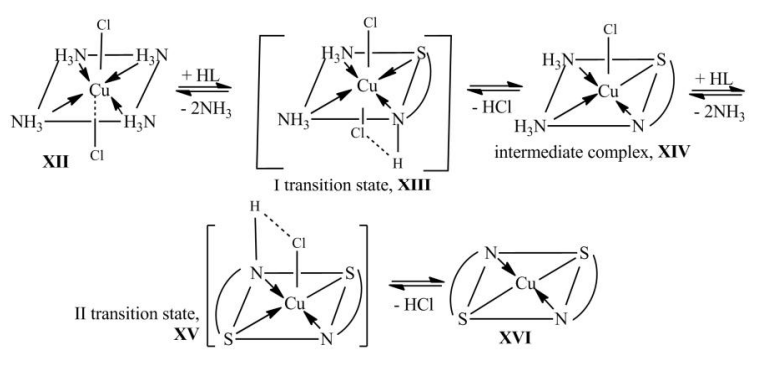

The reactions (6) occur via the dissociation mechanism of the consecutive nucleophilic substitution/elimination of $\mathrm{S}_{\mathrm{N}}^{1} / \mathrm{E}_{1}$ through the formation of intermediate $\left[\mathrm{Cu}\left(\mathrm{NH}_{3}\right)_{2} \mathrm{ClL}\right] \mathbf{X I V}$ and the resulting $\mathrm{CuL}_{2}$ XVI complexes, which are preceded by the formation of intermediates XIII and XIV respectively. Intra-complex dehydrochlorination ( $\beta$-elimination) in intermediates XIII and XIV proceeds quickly. The previously released ammonia binds hydrochloric acid according to the reaction $2 \mathrm{HCl}+2 \mathrm{NH}_{3} \rightarrow 2 \mathrm{NH}_{4} \mathrm{Cl}$, displacing the equilibrium $\mathbf{X I I I} \rightleftharpoons \mathbf{X I V}$ and $\mathrm{XV} \rightleftharpoons \mathrm{XVI}$ towards the resulting complex XVI.

Fig. 1 shows the energy profile of the resulting complex XVI formation, its intermediates XII and XV of I and II transition states, respectively, as well as the intermediate complex XIV. Intermediate XIII has a high activation energy $\Delta G_{1}^{\neq}$, therefore it reacts quickly according to Eq. (6).

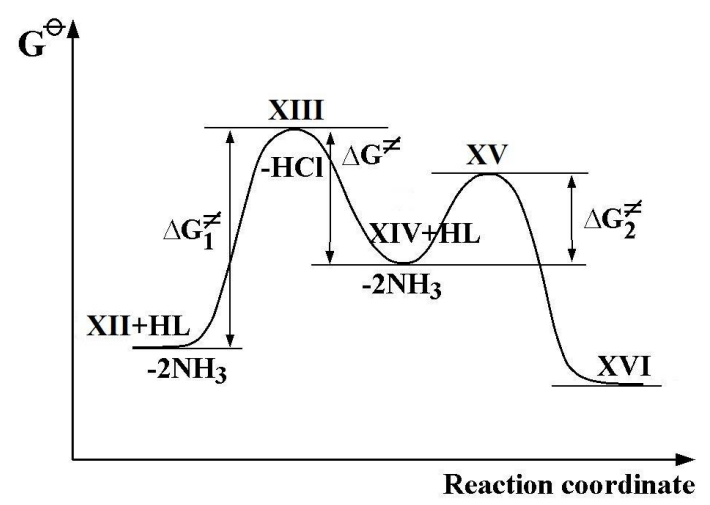

Fig. 1. Energy profile of the resulting complex $\mathrm{CuL}_{2}$ formation, XVI 
The activation energy of the II transition state formation $\Delta G_{2}^{\neq}<<\Delta G_{1}^{\neq}$. It should be noted that during chemical interaction (Eq. (6)) the stereochemistry of the copper(II) complexes is also changed: XII, the octahedron, coordination number (C.N.) $6 \rightarrow \mathbf{X I V}$, the square pyramid, C.N. $5 \rightarrow$ XVI, the flat square, C.N. 4. This fact again indicates the consecutive $\mathrm{S}_{\mathrm{N}}{ }^{1} / \mathrm{E}_{1}$ mechanism of this reaction.

The composition and structure of coordination compounds VII-X, obtained by the method B, were determined by elemental and XRD analysis (compound XI), counter-synthesis (method C), and IR-spectroscopy.

\subsection{Obtaining of $\mathrm{CuL}_{2}{ }^{6-9}$ Chelates by Catalytic Hydrolysis of $\left[\mathrm{Cu}\left(\mathrm{HL}^{6-9}\right)_{2} \mathrm{X}_{2}\right]_{2}$ Complexes, Method C}

Using X-ray method, we established [1] the dimer structure of $\left[\mathrm{Cu}\left(\mathrm{HL}^{6-9}\right)_{2} \mathrm{X}_{2}\right]_{2}$ complexes, the hydrolysis of which in water or alcohol-water medium occurs according to the following general reactions [6]:

$$
\begin{aligned}
& {\left[\mathrm{Cu}(\mathrm{HL}) \mathrm{X}_{2}\right]_{2} \stackrel{+2 \mathrm{H}_{2} \mathrm{O}}{\rightleftharpoons}\left[\mathrm{CuLX}_{2}\right]_{2} \ominus^{\ominus}+2 \mathrm{H}_{3} \mathrm{O} \oplus} \\
& {\left[\mathrm{Cu}(\mathrm{HL}) \mathrm{X}_{2}\right]_{2} \stackrel{2 \mathrm{H}_{3} \mathrm{O}^{\oplus}}{\rightleftharpoons}[\mathrm{Cu}(\mathrm{HL}) \mathrm{X}]_{2}{ }_{+2 \mathrm{H}_{3} \mathrm{O}}{ }^{\oplus} \mathrm{X}^{\ominus}} \\
& \text { XVII XIX } \\
& {\left[\mathrm{Cu}(\mathrm{HL}) \mathrm{X}_{2}{ }^{\oplus}+\left[\mathrm{CuLX}_{2}\right] \stackrel{\mathrm{X}}{\rightleftharpoons} 2 \mathrm{CuL}_{2}+2 \mathrm{CuX}_{2}+2 \mathrm{HX}\right.} \\
& \text { XVIII XIX XVI } \\
& \sum 2\left[\mathrm{Cu}(\mathrm{HL}) \mathrm{X}_{2}\right]_{2} \rightleftharpoons 2 \mathrm{CuL}_{2}+2 \mathrm{CuX}_{2}+4 \mathrm{HX} \\
& \text { XVII XVI }
\end{aligned}
$$

Hydrolysis of reactions (7)-(9) can be considered as a chemocatalytic cascade process in which water is both a catalyst and a solvent. It should be noted that such chemical transformations, in which individual catalytic stages are converted into a multistage catalytic cascade process (for example, the reactions $(7) \rightarrow(8) \rightarrow(9)$ ), are a new promising direction for the development of "green chemistry" $[7,8]$. The beginning of such chemocatalytic process is well explained by HSAB concept. Thus, for the reaction (7): at the dissociation of XVII compound a "hard" acid $\mathrm{H}^{\oplus}$ is formed which interacts with the "hard" basis $\mathrm{H}_{2} \mathrm{O}$ via the reaction: $\mathrm{H}^{\oplus}+\mathrm{H}_{2} \mathrm{O} \rightleftharpoons \mathrm{H}_{3} \mathrm{O} \oplus$.

The cascade process of $\left[\mathrm{Cu}\left(\mathrm{HL}^{6-9}\right)_{2} \mathrm{X}_{2}\right]$ hydrolysis, which is studied in this paper, seems to be more complex:

$$
\begin{aligned}
& {\left[\mathrm{Cu}\left(\mathrm{HL}^{6-9}\right)_{2} \mathrm{X}_{2}\right]_{2} \stackrel{+2 \mathrm{H}_{2} \mathrm{O}}{\rightleftharpoons}\left[\mathrm{Cu}\left(\mathrm{HL}^{6-9}\right) \mathrm{L}^{6-9} \mathrm{X}_{2}\right]_{2} \ominus_{+2 \mathrm{H}_{3} \mathrm{O}} \oplus} \\
& {\left[\mathrm{Cu}\left(\mathrm{HL}^{6-9}\right)_{2} \mathrm{X}_{2}\right]_{2} \stackrel{2 \mathrm{H}_{3} \mathrm{O}^{\oplus}}{\rightleftharpoons}\left[\mathrm{Cu}\left(\mathrm{HL}^{6-9}\right)_{2} \mathrm{X}\right]_{2} \oplus_{+2 \mathrm{H}_{3} \mathrm{O}} \oplus_{\mathrm{X}}^{\ominus}} \\
& {\left[\mathrm{Cu}\left(\mathrm{HL}^{6-9}\right) \mathrm{L}^{6-9} \mathrm{X}_{2}\right]_{2} \stackrel{\ominus}{\stackrel{2 \mathrm{H}_{2} \mathrm{O}}{\rightleftharpoons}}\left[\mathrm{CuL}_{2}^{6-9} \mathrm{X}_{2}\right]_{2}{ }^{2-}+2 \mathrm{H}_{3} \mathrm{O} \oplus}
\end{aligned}
$$

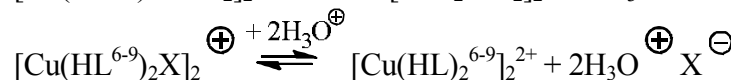

$$
\begin{aligned}
& \frac{\left[\mathrm{Cu}\left(\mathrm{HL}^{6-9}\right)_{2}\right]_{2}^{2+}+\left[\mathrm{CuL}_{2}^{6-9} \mathrm{X}_{2}\right]_{2}^{2-} \rightleftharpoons 4 \mathrm{CuL}_{2}^{6-9}+4 \mathrm{HX}}{\sum 2\left[\mathrm{Cu}\left(\mathrm{HL}^{6-9}\right)_{2} \mathrm{X}_{2}\right]_{2} \rightleftharpoons 4 \mathrm{CuL}_{2}^{6-9}+8 \mathrm{HX}}
\end{aligned}
$$

The $\left[\mathrm{Cu}\left(\mathrm{HL}^{6-9}\right)_{2} \mathrm{X}_{2}\right]$ complexes undergo to deeper hydrolysis, which includes five stages (reactions (11)(15)) and proceeds by the mechanism similar to that given in the reactions (7)-(9).

The composition and structure of coordination compounds VII-X, obtained by the method C, were determined by elemental and XRD analysis, countersynthesis (method B), and IR-spectroscopy.

\subsection{XRD Studies of the Complex Compound [Cu( $\left.\left.\mathrm{C}_{30} \mathrm{H}_{26} \mathrm{Cl}_{2} \mathrm{~N}_{6} \mathrm{O}_{8} \mathrm{~S}_{2}\right)\right]$. i- $\mathrm{C}_{3} \mathrm{H}_{7} \mathrm{OH}, \mathrm{XIII}$}

The crystalline structure of compound $\mathbf{X I}$ is a salt of a complex cation and perchlorate anion (1:2). The complex cation consists of copper(II) cation, thioamide ligand $\mathrm{HL}^{6}$ and isopropyl alcohol (1:2:1). The hydrogen atom of the hydroxyl group in the isopropyl alcohol is objectively observed, which suggests that the copper atom is neutrally coordinated with the isopropyl alcohol molecule.

The copper atom is the five-coordinated atom (coordination polyhedron - distorted square pyramid). The atoms of sulfur and nitrogen forming the basis of the pyramid do not lie in the same plane (the angle between the lines $\mathrm{N}(1) \ldots \mathrm{S}(1)$ and $\mathrm{N}(2) \ldots \mathrm{S}(2)$ is $26^{\circ}$ ), which is probably due to the repulsion between sulfur atoms and atoms of bicyclic fragments (shortened intramolecular bonds $\mathrm{S}(1) \ldots \mathrm{H}(17) 2.88 \AA$ (the sum of van der Waals radii $3.00 \AA[1], \mathrm{S}(2) \ldots \mathrm{C}(2) 3.33 \AA$ (3.55 $\AA), \mathrm{S}(2) \ldots \mathrm{H}(2) 2.75 \AA$ $(3.00 \AA))$.

Bicyclic fragments of the ligands are flat with an accuracy of $0.01 \AA$.

The five-member metal cycle $\mathrm{Cu}(1), \mathrm{S}(1), \mathrm{C}(8)$, $\mathrm{C}(7), \mathrm{N}(1)$ is in the envelope conformation. The deviation of the $S(1)$ atom from the mean square of other atoms is $0.1 \AA$. Metal cycle $\mathrm{Cu}(1), \mathrm{S}(2), \mathrm{C}(23), \mathrm{C}(22), \mathrm{N}(4)$ is flat with an accuracy of $0.01 \AA$. The thionic group $\mathrm{S}(1)=\mathrm{C}(8)$ is somewhat turned relative to the bicyclic fragment (torsion angle $\left.\mathrm{S}(1)-\mathrm{C}(8)-\mathrm{C}(7)-\mathrm{N}(1) 8.9(6)^{\circ}\right)$, whereas the thionic group $\mathrm{S}(2)=\mathrm{C}(23)$ lies in the benzimidazole plane (torsion angle $\mathrm{S}(2)-\mathrm{C}(23)-\mathrm{C}(22)-\mathrm{N}(4) 2.4(5)^{\circ}$ ).

The atoms N(3) and N(6) have a trigonal-planar configuration, despite the shortened intramolecular bonds $\mathrm{H}(3 \mathrm{~N}) \ldots \mathrm{H}(2 \mathrm{~N}) \quad 1.88 \AA(2.32 \AA), \mathrm{H}(3 \mathrm{~N}) \ldots \mathrm{N}(2) \quad 2.43 \AA$ $(2.66 \AA), \mathrm{H}(6 \mathrm{~N}) \ldots \mathrm{H}(5 \mathrm{~N}) 1.78 \AA(2.32 \AA), \mathrm{H}(6 \mathrm{~N}) \ldots \mathrm{N}(5)$ $2.29 \AA(2.32 \AA)$.

The ortho-substituents $\mathrm{C}(9) \ldots \mathrm{C}(15)$ and $\mathrm{C}(24) \ldots \mathrm{C}(30)$ are in the ar-conformation relative to fivemembered metal cycles (torsion angles $\mathrm{C}(9)-\mathrm{N}(3)-\mathrm{C}(8)-$ $\left.\mathrm{C}(7) \quad 179.7(6)^{\circ}, \quad \mathrm{C}(24)-\mathrm{N}(6)-\mathrm{C}(23)-\mathrm{C}(22) \quad 166.6(6)^{\circ}\right)$ and somewhat turned relative to the bond $\mathrm{N}-\mathrm{C}$ (torsion angles $\mathrm{C}(14)-\mathrm{C}(9)-\mathrm{N}(3)-\mathrm{C}(8) 62.2(4)^{\circ}, \quad \mathrm{C}(29)-\mathrm{C}(24)-\mathrm{N}(6)-\mathrm{C}(23)$ 
$\left.60.6(4)^{\circ}\right)$. In this case, shortened intramolecular bonds $\mathrm{C}(14) \ldots \mathrm{S}(1) 3.31 \AA(3.35 \AA), \mathrm{C}(29) \ldots \mathrm{S}(2) 3.33 \AA(3.35 \AA)$ are observed.

Due to rotation around the bond $\mathrm{Cl}(1)-\mathrm{O}(5)$ perchlorate anion $\left[\mathrm{ClO}_{4}\right]^{-}$in the complex $\mathbf{X I}$ exists in two conformations $\mathrm{A}$ and $\mathrm{B}$, with the contributions of 82 and $18 \%$, respectively.

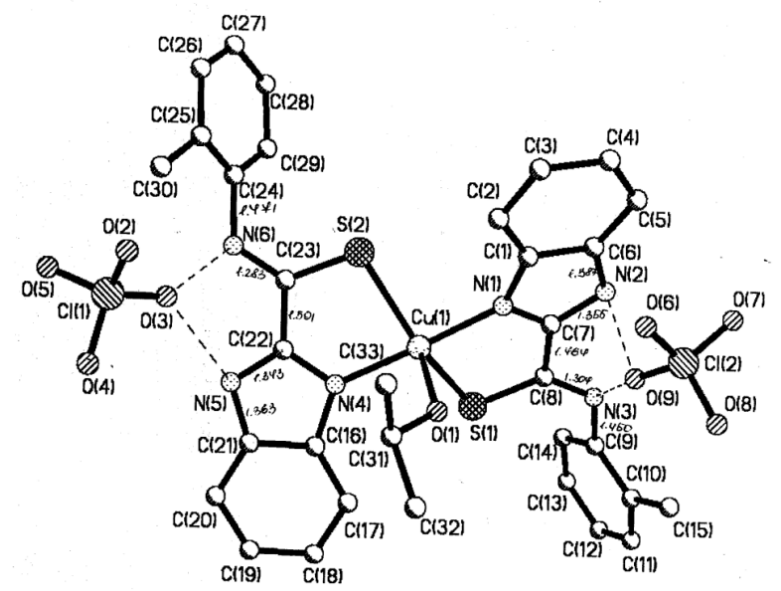

Fig. 2. Molecular structure of complex XI The most important bond lengths, $\AA$ : $\mathrm{Cu}(1)-\mathrm{S}(1) 2.398(5)$, $\mathrm{Cu}(1)-\mathrm{N}(1)$ 1.968(5), $\mathrm{Cu}(1)-\mathrm{S}(2)$ 2.356(4), Cu(1)-N(4) 1.945(5), S(1)-C(8) 1.691(6), N(1)-C(7) 1.317(9), C(7)-C(8) 1.464(9), N(1)-C91) 1.388(4), N(2)-C(7) 1.355(8), N(3)-C(8) 1.305(8), S(2)-C(23) 1.687(7), N(40-C(22) 1.305(8), C(22)$\mathrm{C}(23)$ 1.501(6) N(6)-C(23) 1.284(8), N(4)-C(16) 1.424(9), $\mathrm{N}(5)-\mathrm{C}(22) 1,344(7)$. Valence angles, grad: $\mathrm{N}(1)-\mathrm{Cu}(1)-\mathrm{S}(1)$ 84.6(5), N(1)-Cu(1)-S(2) 93.5(5), N(4)-Cu(1)-S(2) 84.2(4),

$\mathrm{N}(4)-\mathrm{Cu}(1)-\mathrm{S}(1) 96.9$ (6), S(2)-Cu(1)-S(1) 145.8(7),

$\mathrm{N}(4)-\mathrm{Cu}(1)-\mathrm{N}(1)$ 177.6(2), N(4)-Cu(1)-O(1) 91.0(2),

$\mathrm{N}(1)-\mathrm{Cu}(1)-\mathrm{O}(1) 90.5(2), \mathrm{N}(4)-\mathrm{Cu}(1)-\mathrm{S}(2) 84.2(4)$, $\mathrm{O}(1)-\mathrm{Cu}(1)-\mathrm{S}(2) 115.4(7)$
In crystal $\mathbf{X I}$, the complex cation and perchlorate anions are bound together by intermolecular hydrogen bonds: $\mathrm{N}(2)-\mathrm{H}(2 \mathrm{~N}) \ldots 0(9)^{\prime}(-1+x,-0.5-y,-0.5-z)(\mathrm{H} \ldots 0$ $\left.2.03 \AA, \mathrm{N}-\mathrm{H} \ldots 0172^{\circ}\right), \mathrm{N}(3)-\mathrm{H}(3 \mathrm{~N}) \ldots 0(9)^{\prime}(-1+x,-0.5-y$, $-0.5-z) \quad\left(\mathrm{H} \ldots 0 \quad 1.93 \AA, \quad \mathrm{N}-\mathrm{H} \ldots \mathrm{O} \quad 167^{\circ}\right), \quad \mathrm{N}(5)-$ $\mathrm{H}(5 \mathrm{~N}) \ldots \mathrm{O}(3)^{\prime}(1+x, y, z)\left(\mathrm{H} \ldots 01.90 \AA, \mathrm{N}-\mathrm{H} \ldots 0168^{\circ}\right)$, $\mathrm{N}(6)-\mathrm{H}(6 \mathrm{~N}) \ldots \mathrm{O}(3)^{\prime}(1+x, y, z)(\mathrm{H} \ldots 0 \quad 1.89 \AA \AA, \mathrm{N}-\mathrm{H} \ldots \mathrm{O}$ $\left.152^{\circ}\right), \mathrm{O}(1)-\mathrm{H}(1 \mathrm{o}) \ldots \mathrm{O}(4)\left(\mathrm{H} . . \mathrm{O} 1.96 \AA, \mathrm{N}-\mathrm{H} . . . \mathrm{O} 135^{\circ}\right)$.

\subsection{Investigation of Some Coordination Compounds $\left[\mathrm{Cu}(\mathrm{HL})_{2} \mathrm{X}_{2}\right]_{2}$ as Additives to Industrial Oils}

Previously, we investigated the tribotechnical (antiwear $I_{g}$ and antifriction $f_{f r}$ ) properties of lubricating compositions on the basis of industrial oils (I-20, I-20A, I40), which included, as additives, some complexes of copper(II) with heterocyclic thioamides. In the continuation of the above-mentioned works, we investigated the coordination compounds $\left[\mathrm{Cu}(\mathrm{HL})_{2} \mathrm{X}_{2}\right]_{2}$, the tribotechnical properties of which are given in Table.

So, lubricating compositions with mixed-ligand complexes $\left[\mathrm{Cu}(\mathrm{HL})_{n}\left(\mathrm{BF}_{4}\right)_{2}\right]_{2},(n=1$ for comp. $5, n=2$ for comp. 6) have the worst tribotechnical properties. Apparently, this is not only due to the presence of fluorine atoms, because comp. 7 , which includes the $\mathrm{CF}_{3} \mathrm{COO}$ ligand, has substantially better values of $I_{g}$ and $f_{f r}$. The best tribotechnical properties have comp. 3 and $4(n=2)$, which include mixed-ligand complexes $\left[\mathrm{Cu}(\mathrm{HL})_{2}\left(\mathrm{ClO}_{4}\right)_{2}\right]_{2}$ with a perchlorate anion. It should be noted that comp. 1-4 and 7 significantly improve the antiwear (by 3.0-30.0 times) and antifriction (by 2.0-2.9 times) properties of the lubricating compositions compared with the pure oil I-40. Comp. 5 and 6 , on the contrary, degrade them by 1.35 times.

Tribotechnical properties of coordination compounds of the general formula<smiles>[R]c1cccc(NC(=S)c2nc3ccccc3[nH]2)c1</smiles>

\begin{tabular}{|c|c|c|c|c|c|c|c|}
\hline \multirow{3}{*}{$\begin{array}{c}\text { Lubricating } \\
\text { composition } \\
\text { No. }\end{array}$} & \multicolumn{5}{|c|}{ Components of lubricating composition, $\%$} & \multirow{3}{*}{$I_{g} \cdot 10^{-4}, \mathrm{~g}$} & \multirow{3}{*}{$f_{\mathrm{fr}} \cdot 10^{-2}$} \\
\hline & \multicolumn{3}{|c|}{ complex $\mathrm{Cu}(\mathrm{II})$} & \multirow{2}{*}{ DMF } & \multirow{2}{*}{ I-40 oil } & & \\
\hline & $\mathrm{R}$ & $\mathrm{n}$ & $\mathrm{X}$ & & & & \\
\hline 1 & $2-\mathrm{CH}_{3}$ & 1 & $\mathrm{ClO}_{4}$ & 3.0 & up to 100 & 0.50 & 2.65 \\
\hline 2 & $2-\mathrm{Cl}$ & 1 & $\mathrm{ClO}_{4}$ & 3.0 & up to 100 & 0.96 & 1.82 \\
\hline 3 & $\mathrm{H}$ & 2 & $\mathrm{ClO}_{4}$ & 3.0 & up to 100 & 0.20 & 1.98 \\
\hline 4 & $4-\mathrm{CH}_{3}$ & 2 & $\mathrm{ClO}_{4}$ & 3.0 & up to 100 & 0.20 & 1.95 \\
\hline 5 & $\mathrm{H}$ & 1 & $\mathrm{BF}_{4}$ & 3.0 & up to 100 & 2.00 & 7.02 \\
\hline 6 & $4-\mathrm{CH}_{3}$ & 2 & $\mathrm{BF}_{4}$ & 3.0 & up to 100 & 2.00 & 7.00 \\
\hline 7 & $\mathrm{H}$ & 2 & $\mathrm{CF}_{3} \mathrm{COO}$ & 3.0 & up to 100 & 1.00 & 1.82 \\
\hline 8 & \multicolumn{4}{|c|}{$\mathrm{I}-40$} & 100 & 6.00 & 5.20 \\
\hline
\end{tabular}

Note: Investigation conditions: contact load $8 \mathrm{MPa}, T=298 \mathrm{~K}, \tau=3 \mathrm{~h}$; copper(II) complex concentration is $0.05 \%$ (comp. 1-6) and $0.1 \%$ (comp. 7); DMF - N,N-dimethylformamide. 


\section{Conclusions}

New mixed-ligand coordination compounds of the general formula $\left[\mathrm{Cu}\left(\mathrm{HL}^{6-9}\right)_{2} \mathrm{X}_{2}\right]_{2}$, which composition and structure were determined by the elemental analysis and infrared spectroscopy, had been synthesized. For chelates of the general formula $\mathrm{CuL}_{2}^{6-9}$, the amyacate synthesis method via $\mathrm{S}_{\mathrm{N}}^{1} / \mathrm{E}_{1}$ (nucleophilic substitution/elimination) mechanism was proposed and investigated. We synthesized chelates of the general formula $\mathrm{CuL}_{2}^{6-9}$ by the catalytic hydrolysis of mixed-ligand complexes $\left[\mathrm{Cu}\left(\mathrm{HL}^{6-9}\right)_{2} \mathrm{X}_{2}\right]_{2}$. The catalytic cascade mechanism of $\left[\mathrm{Cu}\left(\mathrm{HL}^{6-9}\right)_{2} \mathrm{X}_{2}\right]_{2}$ hydrolysis was proposed.

The spatial structure of the complex compound $\left[\mathrm{Cu}\left(\mathrm{C}_{30} \mathrm{H}_{26} \mathrm{Cl}_{2} \mathrm{~N}_{6} \mathrm{O}_{8} \mathrm{~S}_{2}\right)\right] \cdot i-\mathrm{C}_{3} \mathrm{H}_{7} \mathrm{OH}$, which is a solvated salt of copper(II) complex cation and perchlorate anion (1:2) was investigated using XRD. The tribotechnical characteristics of the lubricating compositions based on industrial oil I-40 and mixed-ligand coordination compounds of the general formula $\left[\mathrm{Cu}(\mathrm{HL})_{2} \mathrm{X}_{2}\right]_{2}$ were investigated in the friction pair "bronze-steel". The significant improvement of these characteristics compared with the pure oil I-40 were shown.

\section{References}

[1] Ranskiy A., Didenko N., Gordienko O.: Chem. Chem. Technol., 2017, 11, 11. https://doi.org/10.23939/chcht11.01.011.

[2] Gordienko O., Titov T., Ranskiy A., Gumenchuk O.: Chem.

Chem. Technol., 2018, 12, 176.

https://doi.org/10.23939/chcht12.02.176
[3] Ranskiy A., Boichenko S., Gordienko O. et al.: Composytsyini Mastylni Materialy na Osnovi Tioamidiv ta ich Complexnykh spoluk. VNTU, Vinnytsa 2012.

[4] Ranskiy A., Didenko N., Gordienko O.: Ukr. Khim. Zh., 2016, 82, 117.

[5] Sheldrick G.: SHELXTL PLUS. PC Version. A system of computer programs for the determination of structure from X-ray diffraction data. Rev. 5.1, 1998.

[6] Ranskiy A.: Koordynacijni Spoluky Dejakych 3d-Metaliv z Aromatychnymy ta Heterocyklichymy Tioamidamy: Doct. thesis. Dnipropetrovsk 2002.

[7] Rodzher A. Sh.: Ros. Khim. Zh., 2004, 48, 74.

[8] Moiseev I.: Uspekhi Khim., 2013, 82, 616.

Received: June 01, 2018 / Revised: June 23, 2018 / Accepted: October 22, 2018

\section{СИНТЕЗ, БУДОВА І ВИКОРИСТАННЯ ЗМШШАНОЛІГАНДНИХ КООРДИНАЦЙНИХ СПОЛУК КУПРУМУ(II) IЗ ЗАМІЩЕНИМИ ТІОАМІДАМИ}

Анотація. Синтезовано нові координаційні сполуки купруму(II) із заміщеними тіоамідами загальної формули

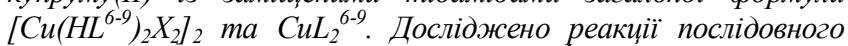
нуклеофільного замішення/елімінування $S_{N}^{1} / E_{1}$ в октаедричному комплексі $\left[\mathrm{Cu}\left(\mathrm{NH}_{3}\right)_{4} \mathrm{Cl}_{2}\right] \cdot \mathrm{H}_{2} \mathrm{O}$ та каталітичного гідролізу комплексів $\left[\mathrm{Cu}\left(\mathrm{HL}^{6-9}\right)_{2} \mathrm{X}_{2}\right]_{2}$. На основі даних елементного та рентгеноструктурного аналізу, ІЧ-спектроскопії встановлено склад $i$ будову синтезованих комплексів. Молекулярну $i$ кристалічну структуру колплексу $\left[\mathrm{Cu}\left(\mathrm{C}_{30} \mathrm{H}_{26} \mathrm{Cl}_{2} \mathrm{~N}_{6} \mathrm{O}_{8} \mathrm{~S}_{2}\right)\right] \cdot i$ $\mathrm{C}_{3} \mathrm{H}_{7} \mathrm{OH}$ встановлено методом рентгеноструктурного аналізу. Досліджено триботехнічні характеристики $\left(I_{g}, f_{m p}\right)$ деяких координачійних сполук як додатків до індустріальних олив.

Ключові слова: заміщені тіоаміди, купрум(II), координаційні сполуки, рентгеноструктурний аналіз, індустріальні оливи. 